\title{
Isolation, Identification and Characterization of Pectinase Producers from Agro Wastes (Citrus sinensis and Ananas comosus)
}

\author{
Adeyefa OM and Ebuehi OAT* \\ Department of Biochemistry, College of Medicine, University of Lagos, Lagos, Nigeria
}

*Corresponding author: Ebuehi OAT, Department of Biochemistry, College of Medicine,

University of Lagos, Lagos, Nigeria.

\begin{abstract}
Fruits detached from the living plants cannot repair its cells or defend its tissues against natural deterioration. Pectinases, the first enzymes to be secreted by fungal pathogens, weakens the plant cell wall and expose other polymers to degradation by hemicellulases and cellulases, are of significant importance in current biotechnological era, with their applications in various industries. The objective of this study, is to isolate and characterize pectinase producers from Bacillus subtilis and Aspergilus niger based on their carbon and nitrogen sources, using different assays. Fresh and rotten orange and pineapple peel were incubated in nutrient broth and the resulting microorganisms Bacillus subtilis and Aspergilus niger were subculture in pectin agar. Pectinase was extracted with pectin agar incubated at room temperature for 6 days. Clear zones of pectinase were isolated for secondary screening by estimating polygalacturonase (PG) and pectin lyase (PL) production under solid state fermentation by using the modified medium. Pectinase activity was analysed by alternating certain parameter, such as temperature and $\mathrm{pH}$. Concentration of D-galacturonic acid and polygalacturonase were adjusted to investigate pectinase activity. The effect of inoculum size $\left(10^{6} \mathrm{CFU} / \mathrm{ml}, 10^{5} \mathrm{CFU} / \mathrm{ml}, 10^{4} \mathrm{CFU} / \mathrm{ml}\right.$ and $10^{3} \mathrm{CFU} /$ $\mathrm{ml}$ ) for the production of pectinase. From this study, $10^{4} \mathrm{CFU} / \mathrm{ml}$ and $10^{3} \mathrm{CFU} / \mathrm{ml}$ were optimum inoculum sizes for the production of pectinase for both rotten and fresh oranges and pineapples respectively with level of significance $(\mathrm{p}<0.05)$. Optimum pectinase activity was recorded at $\mathrm{pH} 5$ and temperature $35^{\circ} \mathrm{C}$ and $30^{\circ} \mathrm{C}$ and $\mathrm{pH} 5$ and temperature $30^{\circ} \mathrm{C}$ and $35^{\circ} \mathrm{C}$ for both fresh and rotten oranges and pineapples respectively. Considering its great significance, with tremendous potential pectinase offers industries, one can conclude that strategic ways to produce maximum pectinase with low cost production should be studied
\end{abstract}

\section{Introduction}

When fruit is detached from the living plants it cannot repair its cells or defend its tissues against natural deterioration. There are many reasons of fruit destruction, but main cause of fruit spoilage is invasion by microorganisms such as mould, yeast and bacteria. Fruits contain high levels of sugars and nutrients and their low $\mathrm{pH}$ make fruits particularly desirable to fungal decay [1]. During postharvest handling, mechanical damage causes the release of enzymes present in the cell tissues. These enzymes break down the cellular material. Pectinases are the first enzymes to be secreted by fungal pathogens when they attack plant cell walls, weaken the plant cell wall and expose other polymers to degradation by hemicellulases and cellulases [2]. Pectinases are one of the most widely distributed enzymes in bacteria, fungi and plants insects, nematodes, plants, and protozoan [3]. Fungi are considered to be prospective enzyme producing sources.

Pectinases breaks down pectin and are of significant importance in the current biotechnological era with their all-embracing applications in fruit juice extraction and its clarification, scouring of cotton, degumming of plant fibers, waste water treatment, vegetable oil extraction, tea and coffee fermentations, bleaching of paper, in poultry feed additives, in alcoholic beverages and food industries [4]. Pectinases constitute approximately $10 \%$ of the total enzyme production in the world market and $25 \%$ of global sale in the food industry [5]. 
In the fruit juice industry, they are used for clarification of fruit juice by reduction in viscosity, increasing of juice yield by enzymatic liquefaction, and maceration of pulps, enhancing pigmentation by extracting more anthocyanin [6]. Microbial pectinases have been widely studied due to the requirement of highly productive strains and the cost-effective production of enzymes. In the present study, the pectinase was purified from a newly isolated Bacillus subtilis strain and this enzyme was characterized Identification and characterization of various pectinase producers have been published. There is paucity of information from the literature on combined action of two fruits and their mode of action. The aim of this study is to isolate and characterize based on primary and secondary screening, pectinase producers and how to optimize them from Agro-wastes, orange and pineapple

\section{Materials and Methods}

\section{Reagents}

The reagents and chemicals used in the study include: Pectin, $\mathrm{K}_{2} \mathrm{HPO}_{4}, \mathrm{MgSO}_{4} \cdot 7 \mathrm{H}_{2} \mathrm{O}, \mathrm{NaCl}, \mathrm{CaCl}_{2} \cdot 2 \mathrm{H}_{2} \mathrm{O}, \mathrm{FeCl}_{3} \cdot 6 \mathrm{H}_{2} \mathrm{O}$, yeast extract, Agar, urea, $\left(\mathrm{NH}_{4}\right) 2 \mathrm{SO}_{4}, \mathrm{MgSO}_{4}, \mathrm{FeSO}_{4}$, and glucose, were all of analytical grade and were purchased from Hi Media and Sigma Chemicals, USA.

\section{Materials}

\section{Collection of samples}

The fresh oranges were plucked from a tree in Alagomeji, Lagos, Nigeria. The fresh pineapples were gotten from a pineapple plantation in Epe, Lagos. The oranges and pineapples which were intended to be rotten were purchased from Mushin market, Lagos, Nigeria. The rottenness of the oranges and pineapples was obtained by leaving the purchased fruits for 14 days on a flat surface in the laboratory.

\section{Isolation of pectinolytic fungi}

Fungi were isolated from the rotten fruits (oranges and pineapples) by using the modified pectin agar medium. In brief, two-fold dilutions of the spoiled samples were plated in pectin agar medium and incubated at room temperature for 6 days. The strains grown in the plate were subcultured into pectin agar medium separately and flooded with $1 \%$ cetrimide for primary screening. The pectinolytic fungi produced a clearing zone when exposed to cetrimide [7].

\section{Secondary screening}

The fungal strains which showed clearing zones in pectin agar medium were selected for secondary screening by estimating the polygalacturonase (PG) and pectin lyase (PL) production under solid state fermentation by using the modified medium [8].

\section{Isolation of pectinolytic bacteria}

The isolates of both the rotten and fresh pineapple were cultured and incubated at $35^{\circ} \mathrm{C}$ for $48 \mathrm{~h}$. Thereafter, the distinct bacteria colonies were streaked on nutrient agar and incubated at $35^{\circ} \mathrm{C}$ for $24 \mathrm{~h}$. When Gram-stained films were examined, the isolates that appeared as Gram-positive rods was identified as Bacillus subtilis based on result from biochemical test as enumerated [9-10]. The Bacillus isolates were maintained in nutrient agar slants at $4{ }^{\circ} \mathrm{C}$.

\section{Enzyme assays}

Polygalacturonase activity was measured according to the method described by [11-13] One unit of enzyme activity has been defined as the amount of enzyme that releases one $\mu$ mol of galacturonic acid /min under the assay conditions [12-13]. Pectin lyase activity was measured by the reaction between unsaturated end products of pectin degradation and thiobarbituric acid. One unit of activity is the amount of enzyme causing a change in absorbance of 0.01 under the conditions of the assay [14].

\section{Effect of inoculum age, inoculum size, and incubation} time

Inoculum age was optimized by inoculating the medium (secondary culture) with inocula (primary culture) of varying age, namely $8,12,16,20$, and $24 \mathrm{~h}$, and assaying the filtered broth for enzyme activity. To study the effect of inoculum size, $\left(10^{3}-10^{6} \mathrm{CFU} /\right.$ $\mathrm{ml}$ ) inoculum was used to inoculate the production medium, and polygalacturonase activity was assayed in the broth. The effect of incubation time was studied by incubating the microorganism in production medium for different time intervals $(24,48,72$ and 96 h) and measuring the enzyme activity.

\section{Effect of temperature and $\mathrm{pH}$}

Most favorable production temperature was studied by incubating the production medium at different temperatures (20, 30,35 and $40^{\circ} \mathrm{C}$ ). Polygalacturonase activity was assayed by using the standard method [11]. For optimizing the production of $\mathrm{pH}$, the production medium varying $\mathrm{pH}$, namely, 4.0, 4.5, 5.0, 5.5, was used for enzyme production, and activity was measured.

\section{Effect of nitrogen source}

The effect of various nitrogen sources $\left(\mathrm{Ca}\left(\mathrm{NO}_{3}\right)_{2},\left(\mathrm{NH}_{4}\right) 2 \mathrm{SO}_{4}\right.$, $\left(\mathrm{NH}_{4}\right) 2 \mathrm{NO}_{3}, \mathrm{NH}_{4} \mathrm{Cl}, \mathrm{NaNO}_{3}, \mathrm{KNO}_{3}$, and Urea on the production of enzyme was studied by supplementing $0.1 \% \mathrm{w} / \mathrm{v}$ of these to the production media.

\section{Effect of D-galacturonic acid on polygalacturonase production}

To study the effect of D-galacturonic acid on polygalacturonase production, it was added to the culture broth at a final concentration of $0.3,0.6,0.9,1.2$, and $1.5 \% \mathrm{w} / \mathrm{v}$ under aseptic conditions. The resulting extracellular polygalacturonase activities produced were measured by estimating the reducing groups produced (Figures $1-6)$. 


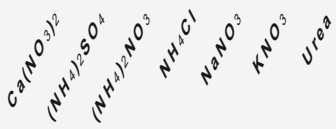

Figure 1: Pectinase activity on fresh and rotten oranges using different Nitrogen sources.

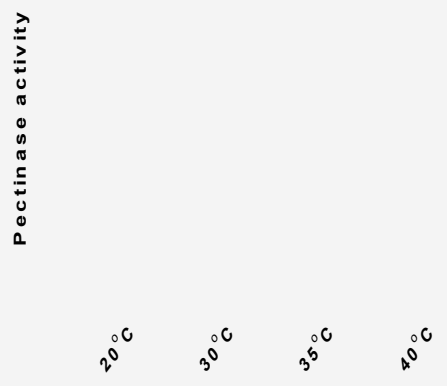

Figure 2: Pectinase activity on fresh and rotten using different.

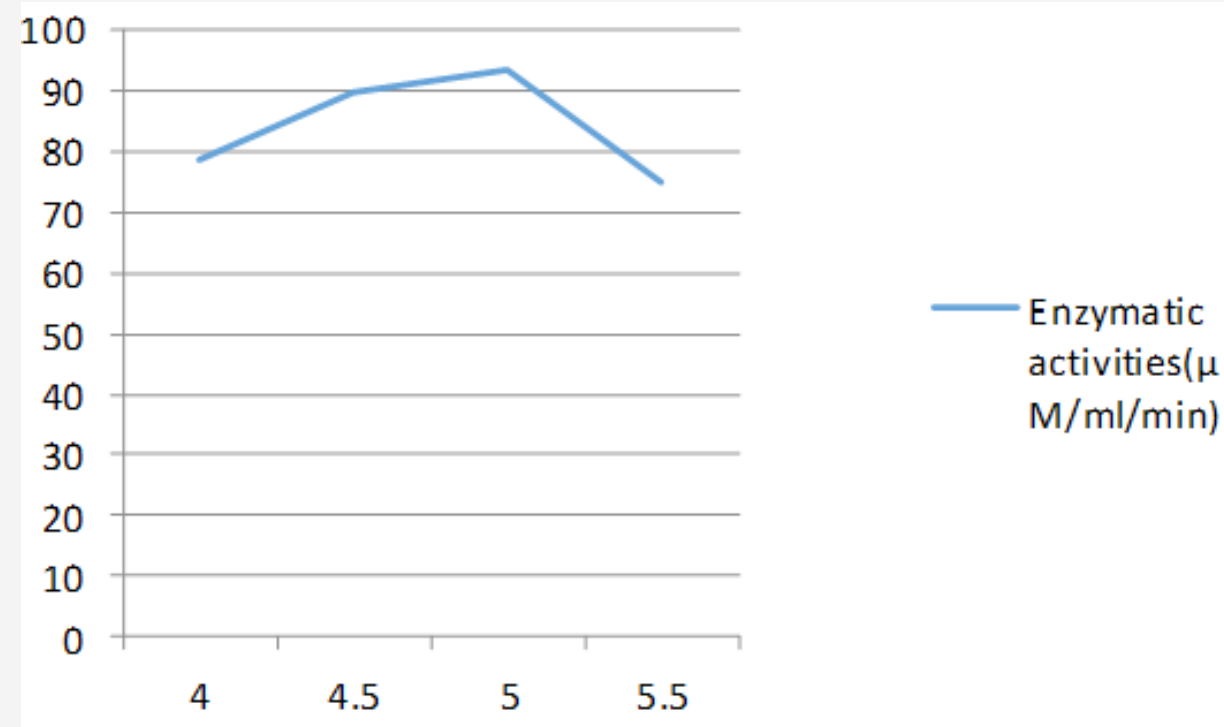

Figure 3: Pectinase activity of fresh oranges at different $\mathrm{pH}(4-5.5)$. 


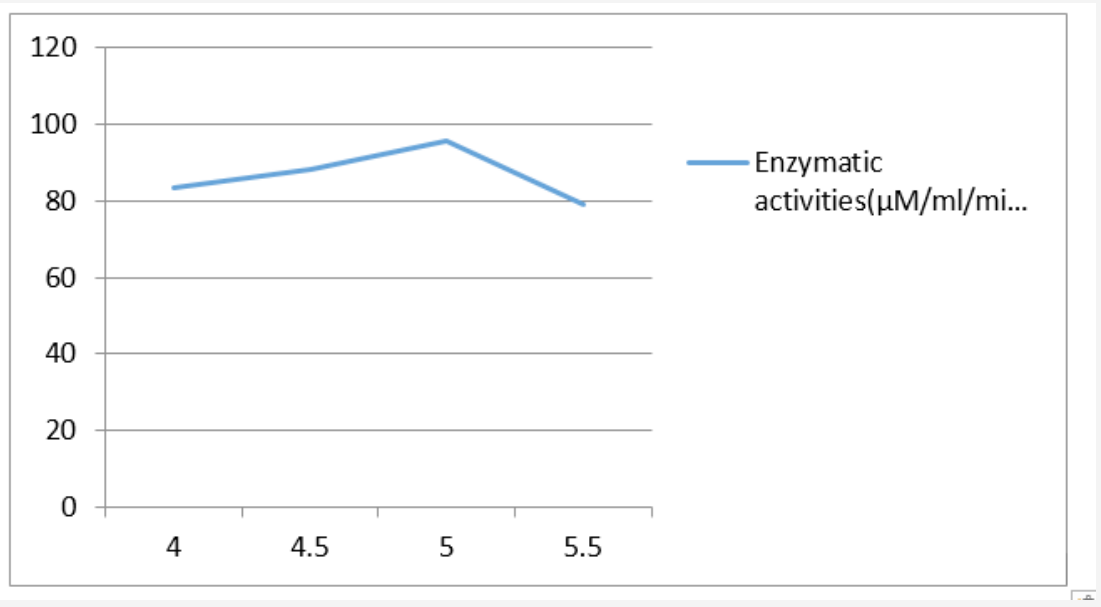

Figure 4: Pectinase activity of rotten oranges at varying $\mathrm{pH}(4-5.5)$.

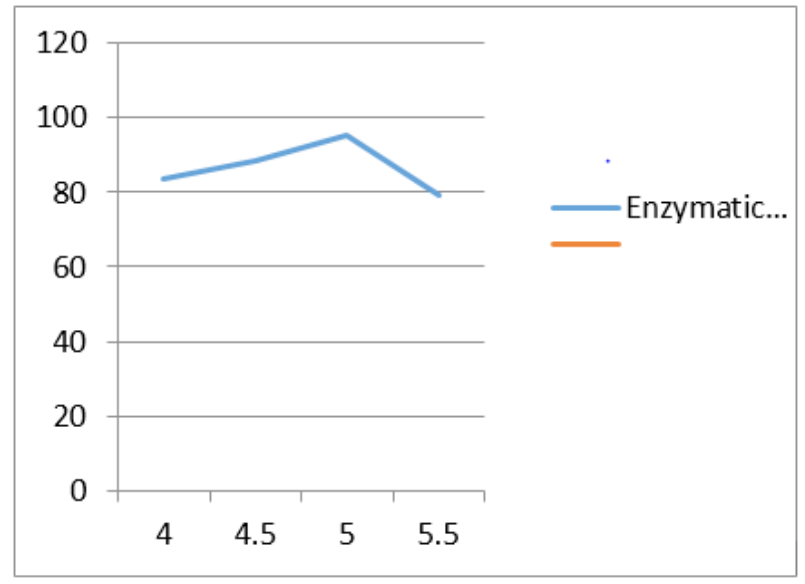

Figure 5: Pectinase activity of fresh pineapple at different $\mathrm{pH}(4-5.5)$.

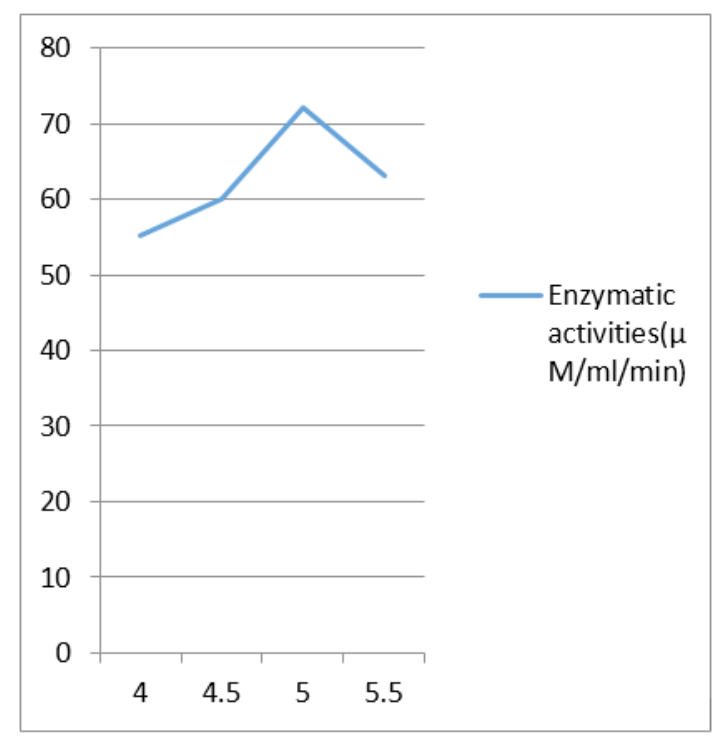

Figure 6: Pectinase activity of rotten pineapple at different $\mathrm{pH}(4-5.5)$. 


\section{Discussion}

Pectinolytic enzyme can be derived from different sources [15-17]. However, pectinase producing microorganisms have due advantage over other sources because they can be subjected to genetic and environmental manipulations to increase yield [18]. It has been reported that most Bacillus $s p$, enhances the production of pectinase [19]. This result indicates that orange and pineapple contain appreciable amount of pectin. The pectin was used as inducer for the production of pectinolytic enzymes. In this study, pectinase production by Bacillus subtilis and Aspergillus niger were compared. Our results show that both Bacillus subtilis and Aspergillus niger were able to produce pectinase. The isolates were later designated based on morphology as Bacillus subtilis, and Aspergillus niger are among the most studied pectinolytic fungi (Sukumaran et al., 2005; Favela-Torres et al., 2006). [20] also has reported that Bacillus $s p$, has produced higher yield of pectinase compared to most other microbes such as Aspergillus.

Temperature is very important factor for microbial growth as well as microbial product formation. The incubation temperature greatly affects the microbial growth rate, enzyme secretion, enzyme inhibition, and protein denaturation. Thermal stability and activity of pectinases are of great significance in biotechnological process. In this study, it was reported that $30^{\circ} \mathrm{C}$ was the optimum incubation temperature for fresh and rotten orange and fresh pineapple but $35{ }^{\circ} \mathrm{C}$ was observed as the optimum incubation temperature for rotten pineapple. In previous report on A. niger, using orange and pineapple D-galacturonic acid as carbon source exhibited maximum activity at $35^{\circ} \mathrm{C}$ which was in accordance to findings by [21].

The initial $\mathrm{pH}$ of the fermentation medium plays a vital role in determining the level of metabolite synthesis. The stability of the microbial metabolite is also dependent on the hydrogen ion concentration of the medium [22]. In this study it was found that the optimum $\mathrm{pH}$ condition for the production of pectinase is $\mathrm{pH} 5$ for fresh and rotten orange and pineapple respectively. According to Spagna et al., 1996, maximum pectinase activity was under $\mathrm{pH}$ 5. The optimum pH from this study is comparable to pectinase of Penicillium varidictum and Penicillium oxalicum [23-25]. [26] reported that optimum $\mathrm{pH} 5.5$ for pectinase activity from thermotolerant Aspergilus sp.

Maximum pectinase activity was observed with $10^{4} \mathrm{CFU} / \mathrm{ml}$ and $10^{3} \mathrm{CFU} / \mathrm{ml}$ inoculums size for both fresh and rotten oranges and pineapples respectively. The effect of inoculum sizes for the production of pectinase fresh and rotten pineapple respectively. Optimum inoculums density is an important consideration for fermentation process since accumulation of spore can inhibit growth and development of the culture organism [27].

An adequate supply of carbon as energy source is critical for optimumgrowth of organismand itsmetabolism. In thepresentstudy, supplementing carbon sources increased pectinase production on solid state. According to [28] low enzyme production with other carbon sources might be because of catabolite repression. Glucose is known to repress the transcription of genes encoding enzymes required for the utilization of alternative carbon sources; some of these genes are also repressed by other sugars such as galactose, [29].The effect of D-galacturonic acid with various concentrations $(0.3 \%, 0.6 \%, 9 \%, 1.2 \%, 1.5 \%)$ was evaluated in this study and it was observed that there were increase in the pectinase activities with increase in the various concentrations of the D-glucoronic acids as [29] found that pectin and polygalacturonic acid promoted the production of pectic enzyme.

The effect of nitrogen sources was also observed in this study for both rotten and fresh oranges and pineapples. Of the various nitrogen sources used, maximum pectinase activity was observed when medium was supplemented with $\mathrm{NH}_{4} \mathrm{Cl}$ for the whole samples. Meanwhile, among the tested nitrogen sources, ammonium sulphate $\left(\mathrm{NH}_{4} \mathrm{SO}_{4}\right)$ and ammonium nitrate $\left(\mathrm{NH}_{4} \mathrm{NO}_{3}\right)$ increased the pectinase productivity on SSF though their effect was not significant. The result is in agreement with [30], who found that ammonium sulphate and ammonium nitrate were good nitrogen sources for pectic enzyme production from A. niger. Moreover, Sarvamangala et al., (2006) revealed that ammonium sulphate did influence production of pectinase positively in solid-state conditions.

\section{Acknowledgement}

The authors are grateful to Miss Olapeju Kazeem for editorial assistance in the preparation of the manuscript.

\section{Conflict of Interest}

No conflict of interest.

\section{References}

1. Singh D, Sharma RR (2007) Postharvest diseases of fruit and vegetables and their management. In: Prasad D (Edn.), Sustainable Pest Management, Daya Publishing House, New Delhi, India.

2. Tomassini A, Selia L, Raiola A, D Ovidio R, Favaron F (2009) Characterization and expression of Fusarium graminearum endopolygalacturonases in vitro and during wheat infection, Journal of Plant Pathology 58(3): 556-564.

3. Torimiro, N. and Okonji REA (2013) Comparative Study of Pectinolytic Enzyme Production by Bacillus Species. African Journal of Biotechnology 12: 6498-6503.

4. Barth M, Hankinson TR, Zhuang H, Breidt F (2009) Microbiological spoilage of fruits and vegetables. Journal of Food Microbiology and Food Safety 1(6): 135-174.

5. Mukesh Kumar DJ, Saranya GM, Suresh K, Andal Priyadharshini D, Rajakumar R, et al. (2012) Production and Optimization of Pectinase from Bacillus sp. MFW7 using Cassava Waste. Asian Journal of Plant Science and Research 2: 369-375.

6. Bayoumi RA, Yassin HM, Swelim MA, Abdel All EZ (2008) Production of Bacterial Pectinase(S) from Agro-Industrial Wastes Under Solid State Fermentation Conditions. Journal of Applied Sciences Research 4: 17081721. 
7. Jayashankar NP, Graham PH (1970) An agar plate method for screening and enumerating pectinolytic microorganisms. Can J Microbiol 16(10): 1023

8. Maldonado MC, Strasser de Saad AM (1998) Production of pectinesterase and polygalacturonase by Aspergillus niger in submerged and solidstate systems, J Ind Microbiol Biotechnol 20: 34-38

9. Breeds R, Murray EGD and Smith NR (1957) Bergey's manual of Determinative Bacteriology $\left(7^{\text {th }}\right.$ edn), The Williams and Wilkins Company, Baltimore USA.

10. Olutiola PO, Famurewa O, and Sonntag HG (1991) An Introduction to General Microbiology: A practical Approach. (1 ${ }^{\text {st }}$ edn) Heidelberg, Germany. pp. 267.

11. Li Q Coffman AM, Ju LK (2015) Development of reproducible assays for polygalacturonase and pectinase. Enzyme Microb Technol 72: 42-48.

12. Nelson N (1944) A photometric adaptation of the Somogyi method for determination of glucose. J Biol Chem 153: 375-380.

13. Somogyi M (1952) Notes on sugar determination. J Biol Chem 195: 1923.

14. Ayers WA, Papavizas GC, Diem A (1966) Polygalacturonate transeliminase production by Rhizoctonia solani. Phytopathol 56: 1006-1011.

15. Whitaker JR (1990) Microbial pectinolytic enzymes. In: Fogarty WM, Kelly CT, editors. Microbial enzymes and biotechnology. 2nd ed. London: Elsevier Science Ltd pp. 133-176.

16. Banu RA, Devi KM, Gnanaprabhal GR, Pradeep BV, Palaniswamy A (2010) Production and characterization of pectinase enzyme from Penicillin chrysogenum. Ind J Sci Technol 3(4): 377-381.

17. Namasivayam E, Ravindar JD, Mariappan KA, Kumar M (2011) Production of extracellular pectinase by Bacillus cereus isolated from market solid waste. J Bioanal Biomed 3: 070-075.

18. Vibha B, Neelam G (2010) Exploitation of microorganisms for screening of pectinase from environment. $8^{\text {th }}$ International Conference. Globelics.

19. Hirose N, Kishida M, Kawasaki H, Sakai T (1999) Purification and Characterization of an Endo Polygalacturonase from a Mutant of Saccharomyces cerevisiae. Biosci Biotechnol Biochem 63(6): 11001103.

20. Kashyap DR, Chandra S, Kaul A, Tewari R (2000) Production, purification and characterization of pectinase from a Bacillus sp. DT7. World J Microbiol Biotechnol 16: 277-282.
21. Saad Naïma, Briand M, Gardarin C, Briand Y, Michaud Philippe (2007) Production, purification and characterization of an endopolygalacturonase from Mucor rouxii NRRL 1894. Enzyme and Microbial Technology 41: 800-805.

22. Jayani RS, Saxena S, Gupta R (2005) Microbial pectinolytic enzymes: a review. Proc Biochem 40(9): 2931-2944.

23. Freitas PM, Martin N, Silva D, da Silva R, Gomes E (2006) Production and partial characterization of polygalacturonases.

24. Silva Dênis, Martins Eduardo da Silva, Silva, Roberto da, Gomes Eleni (2002) Pectinase production by Penicillium viridicatum RFC3 by solid state fermentation using agricultural wastes and agro-industrial byproducts. Brazilian Journal of Microbiology 33(4): 318-324.

25. Zhang CH, Li ZM, Peng XW, Jia Y, Zhang HX, et al. (2009) Separation, purification and characterization of endopolygalacturonase from a newly isolated Penicillium axalicum. Chinese Journal of Process Engineering 9: 242-249.

26. Freitas Paula Mendes de, Martin, Natalia Silva, Dênis Silva, Roberto da, Gomes Eleni (2006) Production and partial characterization of polygalacturonases produced by thermophilic Monascus sp N8 and by thermotolerant Aspergillus sp N12 on solid-state fermentation. Brazilian Journal of Microbiology 37(3): 302-306.

27. Nighojkar Sadhana, Phanse Yashdeep, Sinha Divya, Nighojkar Anand, Kumar Anil (2006) Production of polygalacturonase by immobilized cells of Aspergillus niger using orange peel as inducer. Process Biochemistry 41: 1136-1140.

28. Ahlawat S, Dhiman SS, Battan B, Mandhan RP, Sharma J (2009) Pectinase production by Bacillus subtilis and its potential application in biopreparation of cotton and micropoly fabric. Process Biochem 44(5): 521-526.

29. Beg QK, Bhushan B, Kapoor M, G Hoondal (2000) Production and Characterization. Thermostable Xylanase and Pectinase from Streptomyces Sp. QG-11-3. Journal of Industrial Microbiology and Biotechnology 24: 396-402.

30. Fawole OB, Odunfa SA (1992) Pectolytic moulds in Nigeria, fermentation using agricultural residues and agro-industrial by products. Brazilian Journal of Microbiology 33: 318-324. 